\title{
Augmented Reality Penunjuk Arah Jalan
}

\author{
Monica Caferina Renando ${ }^{1}$, A Sumarudin ${ }^{2}$ \\ ${ }^{1}$ Teknik Informatika Politeknik Negeri Indramayu \\ Indramayu, telp/fax 02345746464 \\ e-mail: ${ }^{1}$ monica.caferina@yahoo.com \\ ${ }^{2}$ Teknik Informatika Politeknik Negeri Indramayu \\ Indramayu, telp/fax 02345746464 \\ e-mail, ${ }^{2}$ asumarudin@gmail.com
}

\begin{abstract}
Abstrak
Augmented reality adalah teknologi dengan konsep menggabungkan dimensi dunia nyata dengan dimensi dunia maya yang ditampilkan secara realtime. Augmented Reality tidak seperti realitas maya yang sepenuhnya menggantikan yang ada di dunia nyata, namun hanya sekedar menambahkan atau melengkapi. Hal ini dilakukan dengan menggambar obyek tiga dimensi pada marker. Marker merupakan 'pola' yang bersifat unik dan dapat dikenali oleh aplikasinya. Smartphone memungkinkan pengembangan aplikasi Augmented Reality dengan mudah serta dapat diakses oleh banyak pengguna. Augmented Reality dapat dimanfaatkan dalam berbagai bidang salah satunya adalah sebagai sarana penunjuk arah jalan untuk mempermudah pengguna jalan. Dalam makalah ini, dikembangkan sebuah aplikasi Augmented Reality yang ditujukan kepada para pengguna jalan sebagai alat penunjuk arah jalan. Aplikasi ini dibuat dengan Vuforia SDK sebagai alat untuk mengembangkan Augmented Reality dengan C\# (C sharp) berbasis Android. Aplikasi Augmented Reality penunjuk arah jalan dapat membaca marker pada petunjuk jalan yang ada pada daerah Bundaran Mangga dan Bundaran Kijang Indramayu, yang akan menampilkan model 3 dimensi di layar perangkat Android dan menampilkan informasi arah jalan berupa linking ke Google Maps. Dari hasil uji coba, aplikasi sudah dapat dibangun dan dapat digunakan untuk membantu pengguna jalan. Aplikasi terganggu dengan kondisi pencahayaan sinar matahari dan jarak pengarahan marker yang tepat.
\end{abstract}

Kata kunci: Augmented Reality, Android, Petunjuk arah jalan

\section{PENDAHULUAN}

Dalam Makalah ini, kami mengembangkan sebuah aplikasi augmented reality berbasis augmented reality yang di kembangkan di platform android. Aplikasi ini augmented ini memungkinkan untuk menampilkan obyek 3D pada dunia nyata dengan tujuan untuk memberikan kemudahan dan interaktif dengan obyek nyata melalaui aplikasi. Aplikasi augmented ini memungkinkan pengguna jalan untuk dapat dengan interaktif dengan plang pentunjuk jalan dengan memunculkan arah jalan berupa obyek 3D, dengan image target (marker) plang jalan. Apllikasi ini memberikan informasi jarak yang ditempuh dari arah yang ditunjuk oleh pengguna dan dapat di hubungkan dengan maps, sehingga memudahkan pengguna jalan untuk mendapatkan informasi posisi mereka dan tujuan akhir dari plang yang di arahkan. Aplikasi dikembangkan dengan menggunakan unity.

\section{METODE PENELITIAN}

Metode penelitian digambarkan di gambar 1 berikut:

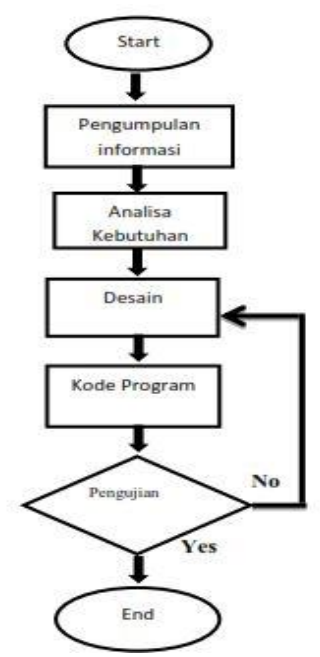

Gambar 1. Metodologi penelitian AR petunjuk jalan

Dalam metodologi yang dilakukan dalam penelitian ini meliputi 5 tahap penelitian. 
1. Tahap pertama merupakan pengumpulan data awal tentang marker jalan yang dijadikan uji coba, literalatur dari penggunakan AR dan unity.

2. Tahap analisa kebutahan dengan mendokumentasikan beberapa kebutuhan aplikasi. Hasil dari tahap pertama di rumuskan dan dibuat dokumen kebutuhan sistem baik dari fungsi setiap aplikasi yang akan dikembangkan, dokumentasi tools yang dipergunakan dan hardware minimum yang dipersyaratkan untuk membangun aplikasi ini.

3. Tahap ketiga merupakan desain sistem yang akan dikembangkan.Perancangan sistem adalah proses menyusun atau mengembangkan sistem informasi yang baru. Dalam tahap ini harus dapat dipastikan bahwa semua prasyaratan untuk menghasilkan sistem informasi dapat dipenuhi. Sistem yang akan dibangun berbasis android. Dalam penerapannya akan dibuat sebuah media penanda yang didalamnya terdapat beberapa objek dengan pola yang telah ditentukan dimana masing-masing objek akan diindentifikasi koordinatnya. Kemudian dari objek-objek yang nantinya akan mendeteksi sentuhan tangan sehingga pada koordinat mana tangan tersebut menyentuh objek maka akan menimbulkan objek yang disentuh melakukan linking ke Google Maps.

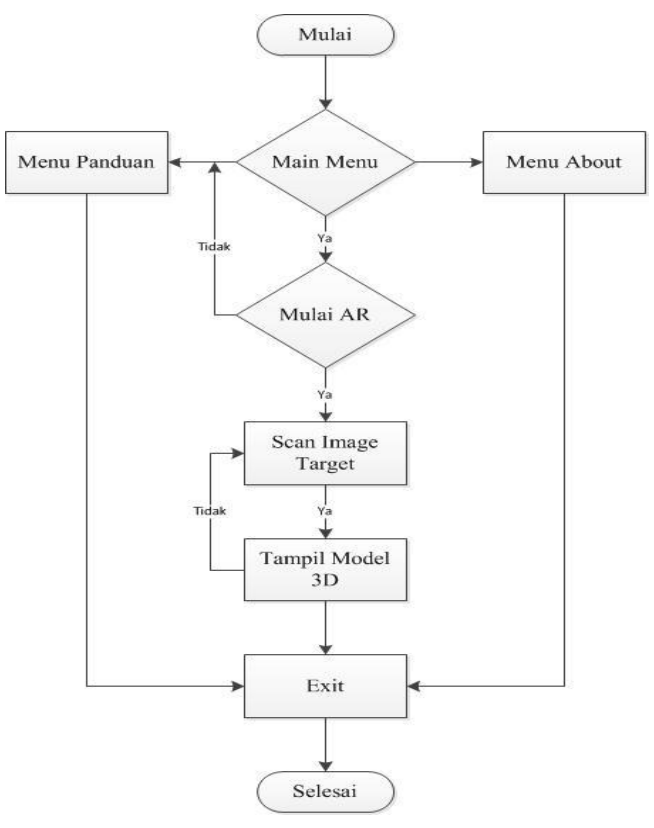

Gambar 2. Diagram Alir Sistem

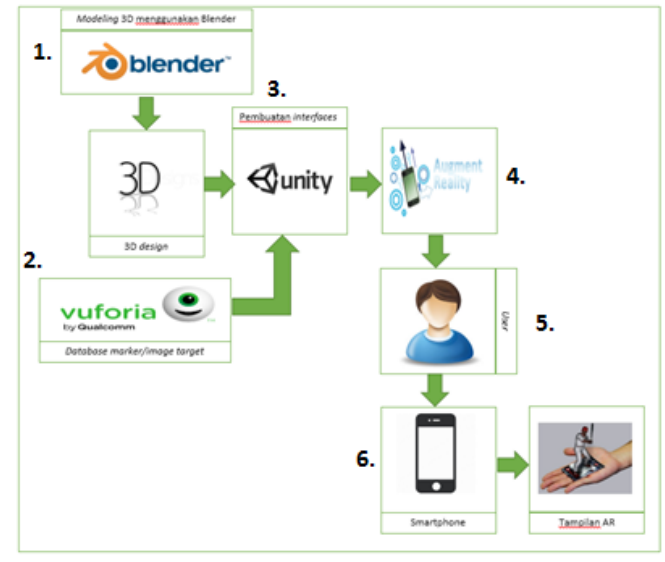

Gambar 3. Rancangan System

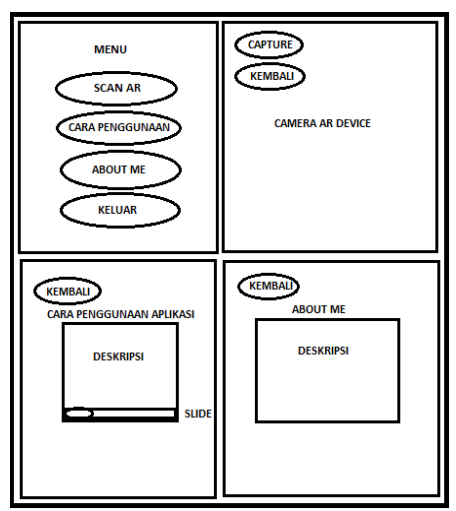

Gambar 4. Perancangan Interface aplikasi

4. Tahap ke empat, pengkodean script yang berdasarkan dari langkah desain. Pengkodean skrip menggunakan tools unity dalam pengembangan aplikasi ini.

5. Langkah terakhir yang dilakukan adalah melakukan pengujian aplikasi menggunakan black box testing. Menggunakan beberapa form yang dipersiapkan dari fungsi dari aplikasi yang di desain di tahap kedua.

\section{IMPLEMENTASI SISTEM}

Penelitian ini menghasilkan sebuah cara untuk dapat memberikan solusi terkait penyediaan informasi mengenai arah mana yang pengguna harus lalui dan berapa jarak yang harus pengguna tempuh untuk mencapai tujuannya, yaitu dengan membuat aplikasi mobile sebagai penunjuk arah yang dilengkapi dengan teknologi Augmented Reality. Dengan demikian aplikasi ini akan memberikan informasi mengenai letak dan arah yang harus ditempuh kepada pengguna dengan mudah. Augmented Reality Penunjuk Arah Jalan ini informasinya bisa diakses di smartphone. Aplikasi penunjuk arah jalan ini merupakan salah satu perangkat lunak yang memanfaatkan teknologi 
Augmented Reality untuk menampilkan 3D pada Image Target. Aplikasi ini berfungsi memberikan informasi berupa peta dan jarak yang ditempuh. Program ini memungkinkan pengembang untuk mengikat animasi atau informasi digital kontekstual dalam program komputer ke Augmented Reality "penanda" di dunia nyata.

\subsection{Prinsip Kerja Perangkat}

Sebelum menjalankan aplikasi, pastikan pengguna telah mengunduh aplikasi ini pada Google Play dan menginstallnya, dipastikan juga device (Smartphone) yang digunakan dalam kondisi baik. Oleh karena aplikasi yang telah dibangun membutuhkan koneksi internet, maka sebelum dilakukan pengujian koneksi internet telah dipastikan dalam keadaan aktif. Setelah aplikasi dijalankan, dan langkah pertama adalah menampilkan Main Menu, Aplikasi ini dilengkapi dengan capture / Scan AR untuk pengambilan Image Target melalui kamera yang ada pada smartphone. Klik Scan AR dan ketika plang jalan disorot kamera sehingga akan keluar 3D arah panah sesuai arah panah yang terdapat di plang jalan tersebut. Ketika arah panah 3D diklik maka akan tampil Informasi dan ketika simbol Google Maps diklik maka langsung mengarahkan ke Google Maps.

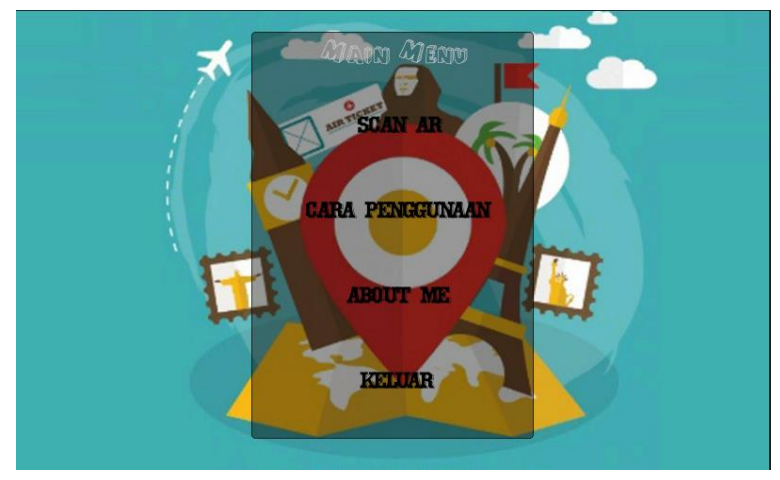

Gambar 5. Tampilan Main Menu

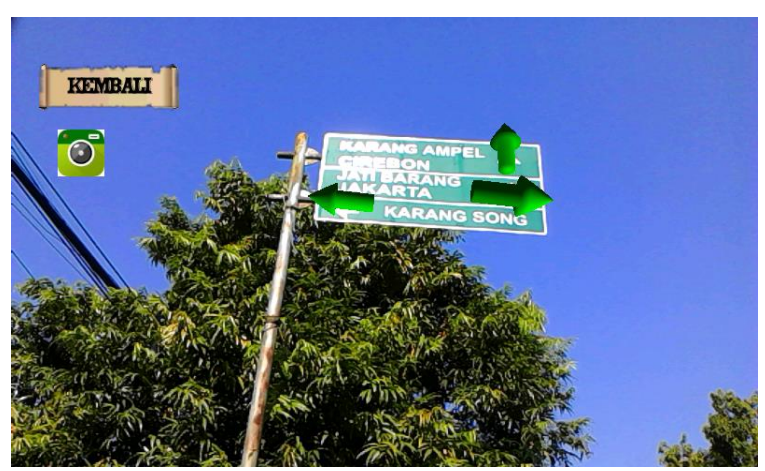

Gambar 6. Scan AR

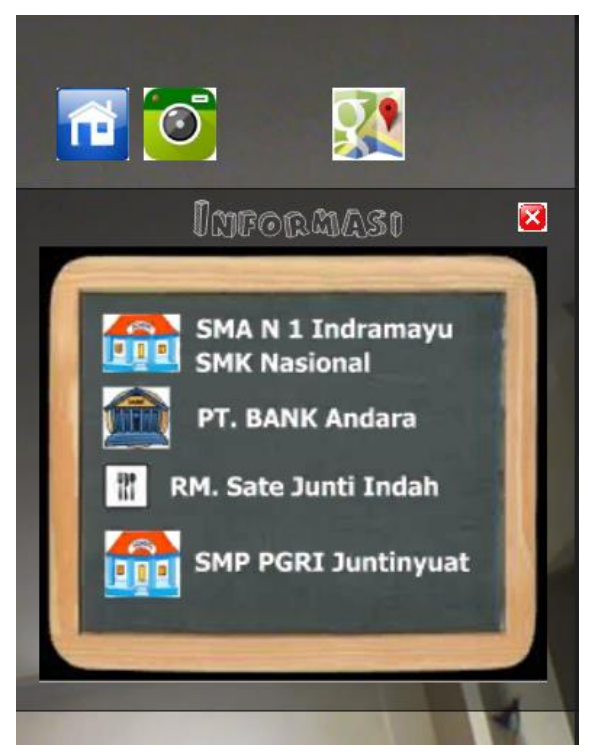

Gambar 7. Informasi Arah Panah yang diklik

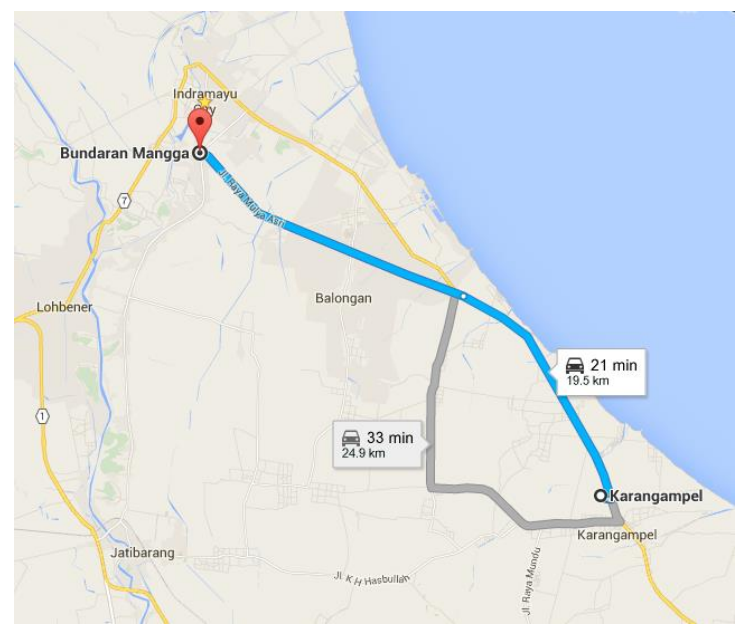

Gambar 8. Menghubungkan dengan maps

\section{HASIL PENGUJIAN}

Pengujian dilakukan secara satu persatu dan hasil pengujian diuraikan pada tabel dibawah sebagai berikut:

Tabel 1. Pengujian fungsi pada aplikasi

\begin{tabular}{|c|c|c|c|}
\hline Halaman & Skenario & $\begin{array}{c}\text { Hasil yang } \\
\text { diharapkan }\end{array}$ & Status \\
\hline $\begin{array}{c}\text { Halaman } \\
\text { Utama }\end{array}$ & $\begin{array}{c}\text { Pilih Scan } \\
\text { AR, Cara } \\
\text { Penggunaan, } \\
\text { About Me, } \\
\text { dan Keluar }\end{array}$ & $\begin{array}{c}\text { Berpindah } \\
\text { kehalaman }\end{array}$ & Berhasil \\
\hline Scan AR & Pilih Scan AR & $\begin{array}{c}\text { Masuk kelayar } \\
\text { kamera untuk } \\
\text { menggunakan } \\
\text { aplikasi } \\
\text { Augmented } \\
\text { Reality }\end{array}$ & Berhasil \\
& & \multicolumn{2}{|c|}{} \\
\hline
\end{tabular}




\begin{tabular}{|c|c|c|c|}
\hline $\begin{array}{c}\text { Layar } \\
\text { AR }\end{array}$ & $\begin{array}{c}\text { Memilih } \\
\text { tombol } \\
\text { capture dan } \\
\text { kembali }\end{array}$ & $\begin{array}{c}\text { Menyimpan } \\
\text { hasil screenshot } \\
\text { dan kembali ke } \\
\text { menu utama }\end{array}$ & Berhasil \\
\hline $\begin{array}{c}\text { Layar } \\
\text { AR }\end{array}$ & $\begin{array}{c}\text { Kesesuaian } \\
\text { tombol yang } \\
\text { terdapat pada } \\
\text { objek }\end{array}$ & $\begin{array}{c}\text { Linking ke } \\
\text { Google Maps }\end{array}$ & Berhasil \\
\hline
\end{tabular}

Tabel 2. Pengujian pada layar smartphone

\begin{tabular}{|c|c|}
\hline Resolusi & Status \\
& \\
\hline WVGA Landcape $(800 \times 480)$ & Berhasil \\
\hline FWVGA Landcape $(850 \times 480)$ & Berhasil \\
\hline WSVGA Landcape $(1024 \times 600)$ & Berhasil \\
\hline WXVGA Landcape $(1280 \times 800)$ & Berhasil \\
\hline 3:2 Landscape & Berhasil \\
\hline 16:10 Lanscape & Berhasil \\
\hline
\end{tabular}

Dari Tabel 2 dapat disimpulkan bahwa smartphone dengan HVGA Landcape (480x320) tidak mendukung aplikasi ini, karena dengan ukuran layar tersebut tampilan dari aplikasi ini tidak beraturan dan tidak dapat dengan jelas menampilkan Augmented Reality.
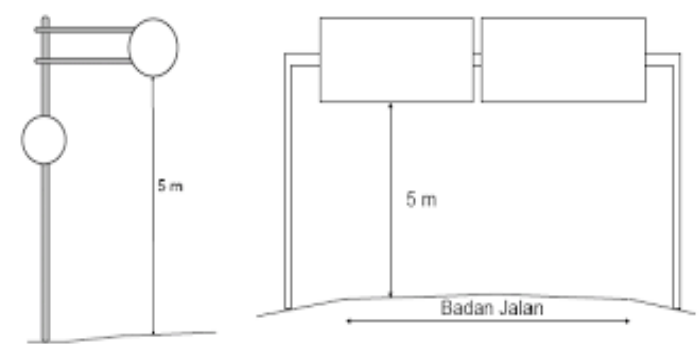

Gambar 9. Tinggi Petunjuk Jalan (sumber : Bidang Lalulintas Dishub)

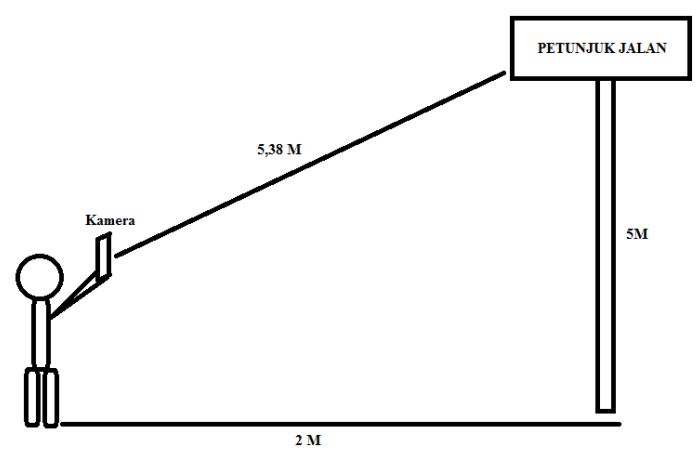

Gambar 10. Jarak dan sudut kemiringan
Tabel 3. Pengujian jarak kamera, sudut kemiringan dan pencahayaan

\begin{tabular}{|c|c|c|c|}
\hline \multicolumn{4}{|c|}{$\begin{array}{l}\text { Hasil Pengujian hubungan jarak antara kamera dan marker, } \\
\text { pantulan cahaya dan sudut kemiringan kamera }\end{array}$} \\
\hline $\begin{array}{c}\text { Jarak } \\
(\mathrm{m})\end{array}$ & $\begin{array}{c}\text { Sudut } \\
\text { kemiringan } \\
\text { kamera }\end{array}$ & Pencahayaan & $\begin{array}{c}\text { Tingkat } \\
\text { keberhasilan }\end{array}$ \\
\hline 2 & $68,198^{\circ}$ & $\begin{array}{l}\text { Sinar matahari, } \\
\text { gelap }\end{array}$ & $\begin{array}{c}\text { Tidak } \\
\text { Berhasil }\end{array}$ \\
\hline 2 & $68,198^{\circ}$ & $\begin{array}{l}\text { Sinar matahari, } \\
\text { berawan }\end{array}$ & Berhasil \\
\hline 2 & $68,198^{\circ}$ & $\begin{array}{l}\text { Sinar matahari, } \\
\text { terik } \\
\text { (membelakangi } \\
\text { petunjuk jalan) }\end{array}$ & $\begin{array}{c}\text { Tidak } \\
\text { Berhasil }\end{array}$ \\
\hline 3 & $59,08^{\circ}$ & $\begin{array}{l}\text { Sinar matahari, } \\
\text { gelap }\end{array}$ & $\begin{array}{c}\text { Tidak } \\
\text { Berhasil }\end{array}$ \\
\hline 3 & $59,08^{\circ}$ & $\begin{array}{l}\text { Sinar matahari, } \\
\text { berawan }\end{array}$ & Berhasil \\
\hline 3 & $59,08^{\circ}$ & $\begin{array}{c}\text { Sinar matahari, } \\
\text { terik } \\
\text { (membelakangi } \\
\text { petunjuk jalan) }\end{array}$ & $\begin{array}{c}\text { Tidak } \\
\text { Berhasil }\end{array}$ \\
\hline 4 & $51,34^{\circ}$ & $\begin{array}{l}\text { Sinar matahari, } \\
\text { gelap }\end{array}$ & $\begin{array}{c}\text { Tidak } \\
\text { Berhasil }\end{array}$ \\
\hline 4 & $51,34^{\circ}$ & $\begin{array}{l}\text { Sinar matahari, } \\
\text { berawan }\end{array}$ & Tidak Berhasil \\
\hline 4 & $51,34^{\circ}$ & $\begin{array}{l}\text { Sinar matahari, } \\
\text { terik } \\
\text { (membelakangi } \\
\text { petunjuk jalan) }\end{array}$ & $\begin{array}{c}\text { Tidak } \\
\text { Berhasil }\end{array}$ \\
\hline 5 & $45^{\circ}$ & $\begin{array}{l}\text { Sinar matahari, } \\
\text { gelap }\end{array}$ & $\begin{array}{c}\text { Tidak } \\
\text { Berhasil }\end{array}$ \\
\hline 5 & $45^{\circ}$ & $\begin{array}{c}\text { Sinar matahari, } \\
\text { berawan }\end{array}$ & $\begin{array}{c}\text { Tidak } \\
\text { Berhasil }\end{array}$ \\
\hline 5 & $45^{\circ}$ & $\begin{array}{l}\text { Sinar matahari, } \\
\text { terik } \\
\text { (membelakangi } \\
\text { petunjuk jalan) }\end{array}$ & $\begin{array}{c}\text { Tidak } \\
\text { Berhasil }\end{array}$ \\
\hline
\end{tabular}

Dari Tabel 4 diatas, jarak dan sudut kemiringan dapat disesuaikan dengan cuaca, karena kondisi cahaya matahari mempengaruhi tampilnya Augmented Reality. Semakin kurangnya cahaya matahari maka diperlukan jarak yang dekat untuk menampilkan Augmented Reality tersebut. Dan sudut kemiringan dapat disesuaikan dengan jarak yang diambil.

Kesimpulan dari hasil pengujian pada Tabel 3 diatas adalah:

1. Terdapat bebrapa faktor yang mempengaruhi tingkat keberhasilan pembacaan marker (petunjuk jalan) yaitu pencahayaan yang cukup dan tingkat kemiringan kamera.

2. Jika pengguna menginginkan pembacaan marker yang tingkat keberhasilannya tinggi, penggunaannya disarankan siang hari atau pencahayaan matahari yang cukup. 
3. Untuk pencahayaan juga jangan terlalu terang atau terlalu gelap karena dapat menyebabkan susahnya pembacaan marker.

\section{PENUTUP}

\section{Kesimpulan}

Dari hasil pengamatan dan percobaan dikaitkan dengan permasalahan dan tujuan dilakukan penelitian ini maka dapat diambil beberapa hal:

1. Aplikasi AR petunjuk arah jalan berhasil dibangun dengan software pengembang Unity dan library Vuforia untuk mengimplementasikan AR,

2. Cara kerja aplikasi AR yaitu sistem Augmented Reality bekerja berdasarkan deteksi citra yang digunakan yaitu marker,

3. Aplikasi mampu menampilkan informasi berupa gambar dan linking ke Google Maps untuk memperjelas posisi dan arah yang akan ditempuh pengguna.

\section{DAFTAR PUSTAKA}

[1] Andi. 2014. Mudah Membuat Game 3 Dimensi Menggunakan Unity 3D, Penerbit ANDI Yogyakarta dengan WAHANA KOMPUTER Semarang.

[2] 2014. Pengertian Augmented Reality. http://www.it-jurnal.com.Diakses pada 20 Maret 2015

[3] 2011.PengertianBlender.https://www. Blender.org . Diakses pada tanggal 21 Maret 2015

[4] 2011.unity.http://unity3dindo.forumid.net/t5mengenal-lebih-dalam-tentang-unity3d. Diakses pada tanggal 20 Maret 2015

[5] 2012.Vuforia.www.developer. vuforia.com. Diakses pada tanggal 20 Maret 2015

[6] Anwar ; Khoerul. 2013. Aplikasi Penunjuk Arah Lokasi Kampus STIMATA Menggunakan Teknologi Augmented Reality.

[7] Azuma, Ronald T. 1997, A Survey of Augmented Reality Presence: Teleoperators and Virtual Environment, http:// www.cs.unc.edu . Diakses pada tanggal 22 Maret 2015

[8] Desi. 2014. Implementasi Augmented Reality. http://www.academia.edu . Diakses pada tanggal 25 Mei 2015

[9] Developer vuforia. 2015. Pembuatan Database Marker. www . developer .vuforia .com. Diakses pada tanggal 4 April 2015.

[10] Jacobs,Dr.Paul E. 2012. Products /augmented-reality. www.qualcom.co.id. http://www.qualcomm.co.id .Diakses pada tanggal 21 Maret 2015
[11] Rafni. 2014. Definisi Adobe Photoshop. http://artdesign.or.id . Diakses pada tanggal 21 Maret 2015

[12] Roedavan, Rickman. 2014. Unity Tutorial Game Engine, Bandung : Penerbit Informatika.

[13] Safaat H, Nazruddin. 2011. Pemrograman Aplikasi Mobile Smartphone dan Tablet PC Berbasis Android, Bandung: Penerbit INFORMATIKA. 